\title{
The Investigation of the Presence of Mites in Some Served Dry Foodstuffs
}

Tüketime Sunulan Bazı Kuru Gıda Maddelerinde Akar Varlığının Araştırılması

\section{Emel Uzunoğlu Karagöz, Cihangir Akdemir, Şahin Direkel, Nejla Cebeci Güler}

Department of Microbiology, Giresun University School of Medicine, Giresun, Turkey

Cite this article as: Uzunoğlu Karagöz E, Akmedir C, Direkel Ş, Cebeci Güler N. The Investigation of the Presence of Mites in Some Served Dry Foodstuffs. Türkiye Parazitol Derg 2017; 41: 92-5.

\section{ABSTRACT}

Objective: Mites are microscopic organisms that lower the quality of life of people who are sensitive to them by causing conditions such as atopic dermatitis, allergic rhinitis, and asthma. These organisms are found in every habitat where humans live. This study was conducted to determine the presence of storage mites in dry food items.

Methods: Various food items were procured 10 times each in 300-gram samples. Mites were extracted with a Berlese funnel apparatus over Erlenmeyer flasks containing $70 \%$ alcohol placed at the end of the funnel stems for over $48 \mathrm{~h}$.

Results: Of 25 food items examined in the study, only six were contaminated by mites. Species of the mites found were Acarus siro (34.6\%), Glycyphagus domesticus (22.8\%), Tyrophagus putrescentiae (16.8\%), Tyrophagus spp. (7.9\%), Rhizoglyphus spp. (1\%), Lepidoglyphus destructor (7.9\%), Cheylettus malacensis (4\%), and Cheylettus spp. (2\%).

Conclusion: Although the results of the study show that the presence of mites in food items sold in open containers at open-air markets or stores was low, we suppose that they can cause important health problems for sensitive people.

Keywords: Mite, food mite, storage mite, Kütahya

Received: 21.05.2016 Accepted: 07.02.2017

Öz

Amaç: Akarlar duyarlı insanlarda atopik dermatit, alerjik rinit ve astım gibi alerjik reaksiyonlara neden olarak yaşam kalitesini düşüren, insanın yaşadığı her ortamda bulunan mikroskobik canlılardır. Bu çalışma kuru gıda maddelerinde akar varlığını belirlemek için yürütülmüştür.

Yöntemler: Çeşitli kuru gıda maddeleri 300'er gramlık miktarlarda 10'ar kez temin edilmiş ve 48 saat süreyle Berlese hunilerinde ışıklandırılmıştır. Gıda numuneleri içindeki akarların düzenek yardımıyla içinde \%70'lik alkol bulunan Erlenmayerlere toplanması sağlanmıştır.

Bulgular: Incelenen 25 gıda örneğinin 6 tanesinde akar tespit edilmiş, bulunan türler A.siro (\%34.6), G.domesticus (\%22,8), T.putrescentiae (\%16,8), Tyrophagus spp. $(\% 7,9)$, Rhizoglyphus spp. $(\% 1)$, L.destructor $(\% 7,9)$, Cheylettus malacensis (\%4), Cheylettus spp. (\%2) olarak teşhis edilmiştir.

Sonuç: Çalışmada pazarlarda veya perakende satış yapılan işyerlerinde açık olarak tüketime sunulan gıda maddelerinde akar varlığı düşük bulunmuştur. Ev gibi uygun ortamlarda kısa sürede çoğalabilmeleri ve duyarlı insanlarda ciddi sağlık problemlerine yol açabilmeleri nedeniyle mevcut durumun önemli olduğu düşünülmektedir.

Anahtar Kelimeler: Akar, gıda akarı, depo akarı, Kütahya

Geliş Tarihi: 21.05.2016 Kabul Tarihi: 07.02.2017

\section{INTRODUCTION}

Mites are microscopic organisms that lower the quality of life for people who are sensitive to them by causing conditions like atopic dermatitis, allergic rhinitis, and asthma (1, 2). These organisms are found in the every habitat where humans live, and some are found in various items of food and called stored food mites or storage mites (3).

The secretion and fecal matter by the mites that infect the dry food have a strong antigenic character and they averagely defecate twenty times in a day. Approximately 100 mites can

Address for Correspondence / Yazışma Adresi: Cihangir Akdemir E.mail: cihangir.akdemir@giresun.edu.tr 
produce $2 \mu \mathrm{g}$ of antigens, and this amount of antigen is sufficient to cause an allergic reaction in humans (4). These microscopic organisms may be found in cheese, foodstuffs, grains, and floors, and these are admitted as risky products for sensitive people (5). It has also been stated that allergic reactions are seen more in atopic people and especially exposed to high concentration of allergen originated mites in early time of their life (6). Food mites with high quantity found in the home environment and in dry storage rooms induce allergic reactions. These are sometimes seen unimportant as well as they can also cause very severe clinical symptoms, which are life threatening for those have with high predisposing factors like asthma. Mites in cereals storage are factors of occupational disease, and they can cause dermatitis, allergic rhinitis, asthma, and conjunctivitis for the sectoral employees including farmers (7). The annual rate of increase over the high sensitive person is approximately $1 \%$ and $5 \%$ of the world's population is at the present time sensitive to allergen of mites (5). Although mites of dust/ food, prevalence and the risk of allergy development have been examined many times in Turkey (8-10), studies conducted for parasitological purposes in a wide range of dry food products are limited. This study is aimed at making up for this deficiency by determining food mites that are present in dry food products sold in open bazaars and dry food sellers. Furthermore, the situation from the point of public health is evaluated.

\section{METHODS}

Samples (300 g) of unpacked foodstuffs were procured in nylon bags and then sealed. These samples were sunflower seeds, pumpkin seeds, pistachios, roasted chickpeas, almonds, hazelnuts, walnut kernels, flour, corn flour, whole wheat flour, corn starch, rice starch, lentils, chickpeas, white beans, rice, bulgur, semolina, wheat, corn, dried apricots and figs, pasta, noodles, and tarhana. Samples were tried to examine in $72 \mathrm{~h}$, and if necessary, waited in temperate and dark places during this time.
Mites were extracted using a Berlese funnel apparatus (funnels had a diameter of $25 \mathrm{~cm}$ and height of $35 \mathrm{~cm}$, with 1-2-mm mesh screens that were fitted with $30 \mathrm{~W}$ tungsten filament lamps at an appropriate distance) over Erlenmeyer flasks containing 70\% alcohol placed at the end of the funnel stems over $24 \mathrm{~h}$.

Extracted mites were collected in flacons that contained preserving fluid $(15 \mathrm{~mL}$ glycerin $+90 \mathrm{~mL}$ distilled water+300 mL 95\% alcohol), and these flacons were labeled for information of samples until the identification.

Obtained mites were prepared on microscopic slides by using 2-3 drops of Hoyer's medium $(50 \mathrm{~mL}$ distilled water $+20 \mathrm{~mL}$ glycerin+30 g gum arabicum+200 g chloral hydrate). Slides were dried in an incubator at $60^{\circ} \mathrm{C}$. Mites were identified under a light microscope (Nicon Eclipse E100, Japan) (10x and 40x) using previously proposed classifications (11-14). Approval from the local ethics committee was not required due to the nature of the study.

\section{RESULTS}

In this study, unpackaged dry foodstuffs were taken from the bazaar and seller of dried fruit and nuts grocery markets - provided in total ten times- in 2012 and 2013 (Table 1). Samples were fully examined with the Berlese method.

Mites were only found in six of the following items: noodles (home made, whole wheat flour, corn flour, wheat, and pumpkin seeds (Table 2). In other samples there were no mites.

\section{DISCUSSION}

Although Acarus siro was one of the most prevalent species found in foodstuffs around different places of Turkey, some researchers also paid attention to Lepidoglyphus destructor, Glycyphagus domesticus, Proctolaelaps pomorum, Cheylettus malaccensis, C. eruditus, L. michaeli, Tyrophagus putrescentiae

Table 1. Presence of food mites

\begin{tabular}{|c|c|c|c|c|c|c|c|c|c|c|}
\hline 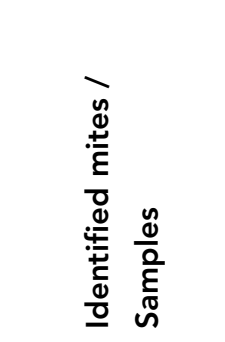 & $\begin{array}{l}0 \\
. \frac{1}{4} \\
\frac{0}{3} \\
\frac{1}{\pi} \\
\frac{U}{4}\end{array}$ & 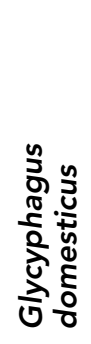 & 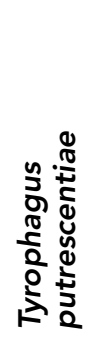 & $\begin{array}{l}\frac{0}{0} \\
\frac{0}{n} \\
\frac{n}{2} \\
0 \\
0 \\
\frac{0}{1} \\
\frac{2}{0} \\
\frac{1}{2}\end{array}$ & $\begin{array}{l}\frac{0}{0} \\
\frac{0}{n} \\
0 \\
\frac{1}{0} \\
\frac{0}{2} \\
\frac{2}{0} \\
\frac{N}{1} \\
\frac{N}{0}\end{array}$ & 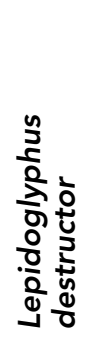 & 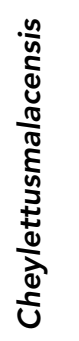 & 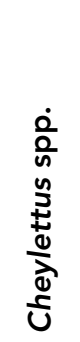 & 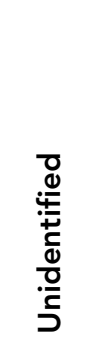 & $\begin{array}{l}\bar{\pi} \\
\stackrel{0}{0}\end{array}$ \\
\hline $\begin{array}{l}\text { Noodles } \\
\text { (Home made) }\end{array}$ & 12 & 6 & 6 & 2 & 1 & - & 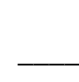 & 1 & 1 & 29 \\
\hline Wheat & 10 & 3 & 3 & 2 & - & 4 & 2 & 1 & - & 25 \\
\hline Flour & 8 & 3 & - & - & - & - & 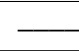 & - & 1 & 12 \\
\hline $\begin{array}{l}\text { Whole wheat } \\
\text { flour }\end{array}$ & 3 & 7 & 4 & 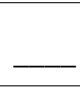 & $\longrightarrow$ & 4 & 1 & - & 1 & 20 \\
\hline Corn flour & 2 & - & - & 4 & - & - & 1 & - & - & 7 \\
\hline $\begin{array}{l}\text { Pumpkin seeds } \\
\text { (uncooked) }\end{array}$ & $\longrightarrow$ & 4 & 4 & $\longrightarrow$ & $\longrightarrow$ & $\longrightarrow$ & $\longrightarrow$ & - & $\longrightarrow$ & 8 \\
\hline Total & 35 & 23 & 17 & 8 & 1 & 8 & 4 & 2 & 3 & 101 \\
\hline
\end{tabular}


Table 2. The number of positive samples and the rates of infestation

\begin{tabular}{|l|c|c|c|}
\hline $\begin{array}{l}\text { Mite } \\
\text { positive } \\
\text { samples }\end{array}$ & $\begin{array}{c}\text { Number of } \\
\text { examined } \\
\text { samples (n) }\end{array}$ & $\begin{array}{c}\text { Number of } \\
\text { positive } \\
\text { samples (n) }\end{array}$ & $\begin{array}{c}\text { Rate of } \\
\text { infestation } \\
\text { (\%) }\end{array}$ \\
\hline $\begin{array}{l}\text { Noodles } \\
\text { (home made) }\end{array}$ & 10 & 3 & 30 \\
\hline Wheat & 10 & 2 & 20 \\
\hline Flour & 10 & 1 & 10 \\
\hline Whole wheat flour & 10 & 2 & 20 \\
\hline Corn flour & 10 & 1 & 10 \\
\hline $\begin{array}{l}\text { Pumpkin seeds } \\
\text { (uncooked) }\end{array}$ & 10 & 2 & 20 \\
\hline
\end{tabular}

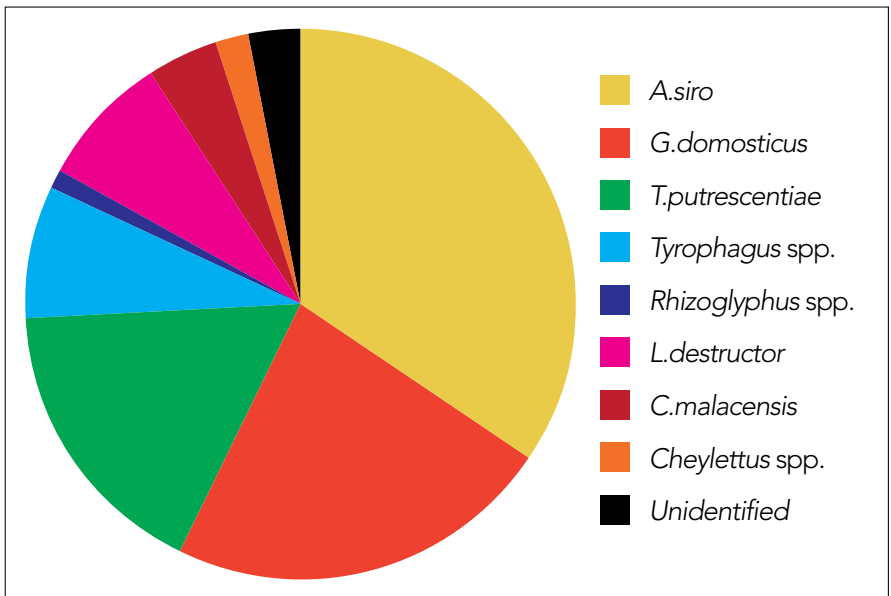

Figure 1. Proportion of identified mites

and Quadroppia quaricarinata $(7,15,16)$. Samples of dry foodstuffs obtained from markets were contaminated with mites at a rate of $47.02 \%$. Contamination was most prevalent in wheat, wheat bran, and wheat debris, and the most common species of mites were A. siro (43.15\%), L. destructor (26.97\%), and T. putrescentiae (13.69\%) (14).

Thin and Clarke (17) detected mites at a rate of $28 \%$ in purchased flour. The most detected species were A. siro, T. putrescentiae, L. destructor, and G. domesticus. Similarly, Palyvos et al. (18) detected mites at a rate of $14.8 \%$ in samples obtained from commercial storages and identified the following species were A. siro, L. destructor, and Chortoglyphus arcuatus. Matsumoto and Satoh (19) also determined T. putrescentiae at the rate of $0.6 \%$ in flour samples obtained from food retail outlets. Ardesehir et al. (20) also determined A. siro as the dominant species in wheat kernels, straw, and dust samples that were obtained from silos and grain mills, and L. destructor (11.94\%) and T. putrescentiae $(0.025 \%)$ were also present in the samples. Furthermore, Ardesehir et al. (20) reported that $96 \%$ of $A$. siro and $74 \%$ of $L$. destructor were obtained from flour mills and T. putrescentiae was obtained only from the grain samples that were taken from the silos. On the other hand, Cotter et al. (21) pointed out that they never detected mites in the samples obtained from storages and shops. In our research, the mites were found in flour (whole wheat flour, wheat flour, and corn flour), homemade baked noodles, and wheat kernel. The mites were determined in two samples of whole wheat flour (wheaten), pumpkin seeds, and wheat kernel samples $(20 \%)$; three samples of noodles (30\%); and one sample of flour and corn flour (10\%) (Table 2). A. siro (34.6\%), G. domesticus (22.8\%), T. putrescentiae (16.8\%), Tyrophagus spp. (8\%), Rhizoglyphus spp. (1\%), L. destructor (8\%), C. malaccensis (3.9\%), and Cheylettus spp. (2\%) were determined in these products while analyzing the general majority of mites in the food samples (Figure 1). It is understood that these mites were originated from $28.7 \%$ from noodles, $24,7 \%$ from wheat kernel, 19.8\% from whole wheat flour (wheaten), 11.8\% from flour, $8 \%$ from pumpkin seeds, and $7 \%$ from corn flour samples. The number of mites per gram of sample was 0.306 in positive samples.

Though Cotter et al. (21) examined the sample-taken randomly with a spatula from the samples-directly under a stereo microscope, Palyvos et al. (18) used the Berlese funnel method, Thin and Clark (17) and Matsumoto (19) preferred the flotation method. Although we used the same method as Palyvos et al. (18) and Ardeshir et al. (20) in our study, we suppose that the reason for detecting fewer mites is that we obtained the materials from district bazaar rather than commercial storages, silos, and flour mills.

Palyvos et al. (18) notified that the ratio of infestation in flour and wheat obtained from commercial storages is $48.3 \%$ and in other products is $48.1 \%$. In our study it is stated that for all the examined samples the ratio is $2.4 \%$ and for the six positive products is $18.3 \%$. It is thought that determined mites are low in both positive samples and products because of the method, the way how to obtain materials and the climatic characteristics of the region.

It is stated that the present factors while packing the dry food products may proliferate in the first monthly period at home environment $(21,22)$. Furthermore, mites present in home dust can infect dry food products (19).

\section{CONCLUSION}

Because of the method of research, the sort of sampling and the differences in places (shops, bazaar, commercial storage facilities, flour mills, wholesalers) where the samples were obtained, the feature of the regional continental climate, less quantity and less intensity of mites than expected have been detected than also we think that they can cause important health problems in sensitive people because of their persistent existence in home environment and sharp increase in number.

Ethics Committee Approval: Approval from the ethics committee was not required in this study.

Informed Consent: N/A

Peer-review: Externally peer-reviewed.

Author Contributions: Concept - C.A.; Design - C.A., E.U.K.; Supervision - C.A., N.C.G.; Materials - C.A, E.U.K., N.C.G., Ş.D.; Data Collection and/ or Processing - Ş.D., E.U.K., N.C.G., Ş.D., C.A.; Analysis and/or Interpretation - N.C.G., E.U.K., Ş.D.; Literature Review - C.A., N.C.G., E.U.K., S..D.; Writing - C.A., E.U.K., N.C.G., Ş.D.; Critical Review - N.C.G., C.A, S..D., E.U. 
Conflict of Interest: No conflict of interest was declared by the authors.

Financial Disclosure: This work was supported (2012/20) by the Dumlupinar University Research Funding.

Etik Komite Onayı: Bu çalışma için etik kurum onayına gerek yoktur.

\section{Hasta Onamı: N/A}

Hakem Değerlendirmesi: Dış bağımsız.

Yazar Katkıları: Fikir - C.A.; Tasarım - C.A., E.U.K.; Denetleme - C.A., N.C.G.; Veri Toplanması ve/veya İşlemesi - Ş.D., E.U.K.; Analiz ve/veya Yorum - N.C.G., E.U.K., Ş.D.; Literatür Taraması - C.A., N.C.G., E.U.K., S..D.; Yazıyı Yazan - C.A., E.U.K., N.C.G., Ş.D.; Eleştirel İnceleme - N.C.G., C.A., Ş.D., E.U.K.

Çıkar Çatışması: Yazarlar çıkar çatışması bildirmemişlerdir.

Finansal Destek: Bu araştırma Dumlupınar Üniversitesitesi Araştırma Fonu tarafından (2012/20) desteklenmiştir.

\section{REFERENCES}

1. Cevizci S, Gökçe S, Bostan K, Kaypmaz A. A wiev of mites infestation cheese and stored foods in terms of public health. T Parasitol Derg 2010; 34: 191-9.

2. Gökce S, Cevizci S, Kaypmaz A. House Dust Mites from Public Health's Perspective. TAF Prev Med Bull 2010; 9: 695-702. [CrossRef]

3. Fernandez-Caldaz E, Puerta L Caraballo L. Mites and allergy. Chem Immunol Allergy 2014; 100: 234-42. [CrossRef]

4. Arlian LG, Morgan MS, Neal JJS. Dust mite allergens: ecology and distribution. Curr Allergy Asthma Rep 2002; 5: 401-11. [CrossRef]

5. Sander I, Zahradnik E, Kraus G, Mayer S, Neumann HD, Fleischer C, et al. Domestic mite antigens in floor and airborne dust at workplaces in comparison to living areas: a new immunoassay to assess personal airborne allergen exposure. PLoS One 2012; 7: e52981. [CrossRef]

6. Celebioglu E, Ozturk AB, SG Comert, Karakaya G, Kalyoncu AF. Storage mite sensitisation is associated with early life village residence in Turkey. Allergol Immunopathol 2013; 4: 402-6. [CrossRef]

7. Stejskal V, Hubert J. Risk of occupational allergy to stored grain arthropods and false pest risk perception in Czech grain stores. Ann Agric Environ Med 2008; 15: 29-35.
8. Akdemir C, Soyucen E. Sensitization of children to storage mites in Kutahya, Turkey. Korean J Parasitol 2009; 47: 387-91. [CrossRef]

9. Akdemir C, Gürdal H. Housedust mites in Kutahya. Turkiye Parazitol Derg 2005; 29: 110-5.

10. Gulbahar O, Mete N, Kokuludag A, Sin A, Sebik F. House dust mite allergens in Turkish homes. Allergy 2004; 59: 231. [CrossRef]

11. Fain A, Guerin B, Hart BJ. Mite and allergic diseases. Allerbio, Varennes en Argonne, 1990.

12. Colloff MJ, Spieksma M. Pictorial keys for the identification of domestic mites. Clin Exp Aller 1992; 22: 823-30. [CrossRef]

13. Hart BJ, Fain A. Morphological and biological studies of medically important house-dust mites. Acarologia 1988; 29: 284-95.

14. Zhang, Zhi-Qiang (2003). Mites of greenhouses: Identification, biology and control. Wallingford, Oxon, GBR; Cabi Publishing. [CrossRef]

15. Kilıc N. Identification of stored product mites, population densities, hosts with the biology of the important one in and around Tekirdag province [PhD thesis]. Ankara University Graduate School of Natural And Applied Sciences, Department of Plant Protection, Turkey; 2000.

16. Kilıc N, Toros S. Investigations on the development of Acarus siro (Acarina:Acaridae) on various food products. Turk Entomol Derg 1997; 21: 133-46.

17. Thind BB, Clarke PG. The occurrence of mites in cereal-based foods destined for human consumption and possible consequences of infestation. Exp Appl Acarol 2001; 25: 203-15. [CrossRef]

18. Palyvos NE, Emmanouel NG, Saitanis CJ. Mites associated with stored products in Greece. Exp Appl Acarol 2008; 44: 213-26. [CrossRef]

19. Matsumoto T, Satoh A. The occurrence of mite-containing wheat flour. Pediatr Allergy Immunol 2004; 15: 469-71. [CrossRef]

20. Ardeshir F, Porshekoh AY, Saboori A. A faunistic study and population fluctuations of mites associated with stored wheat in Tehran region, Iran. Journal of Entomological Society of Iran 2008; 27 : 17-28.

21. Cotter M, Siebers R, Pike A, Fitzharris P, Crane J. Storage Mites in Flour Samples in Wellington, New Zealand. J Investig Allergol Clin Immunol 2011; 21: 410-1.

22. Hubert J, Nesvorna M, Volek V. Stored product mites (Acari: Astigmata) infesting food in various types of packaging. Exp Appl Acarol 2015; 65: 237-42.[CrossRef] 